\title{
AGGREGATE RELATIVE DEPRIVATION AND MACROECONOMIC IMBALANCES IN THE EURO AREA - A FIRST LOOK ${ }^{1}$
}

\begin{abstract}
This paper puts the problem of macroeconomic imbalances in the euro area in an unconventional perspective, focusing on more intense interpersonal income comparisons between individuals from different euro area countries after introduction of a common currency. Costs and benefits of monetary integration (associated with more intense income comparisons) are expressed in terms of aggregate relative deprivation $(A R D)$. It is demonstrated empirically that for 12 euro area countries greater cumulative costs of monetary integration expressed in $A R D$ terms ("ARD losses") in the euro area are positively correlated with greater cumulative increase in the general price level, in the unemployment rate and greater budgetary deficits. No statistically significant relationship was found for appreciation of the real effective exchange rate, nor current account deficits.
\end{abstract}

Keywords: aggregate relative deprivation, income comparisons, macroeconomic imbalances, inflation, unemployment

*E-mail adres: julia.wlodarczyk@ue.katowice.pl.

1 This research project was funded by the National Science Centre (grant number DEC-2013/09/D/HS4/01157). 


\section{Introduction}

There is a growing body of literature documenting macroeconomic imbalances in the euro area. From the point of view of adjustment processes accompanying economic convergence, countries characterized by lower levels of income per capita and lower productivity are expected to observe inflow of foreign capital, higher wage demand, accelerating inflation, appreciation of the real exchange rate, loss of international competitiveness, current account deficits and presumably budgetary deficits. It is also argued that alternatives to the economic convergence hypothesis should be taken into account and that behavioral considerations can accompany analysis of economic fundamentals (cf. e.g. Holinski, Kool, Muysken, 2010). It is worth emphasizing that increased wage pressure, occurring especially in countries with relatively low levels of income per capita, may result from wage transparency achieved within the monetary union. As Clark \& Senik (2010) demonstrated, income comparisons are important for three quarters of Europeans. This justifies augmenting traditional analyses of macroeconomic imbalances to include such concepts like relative deprivation which is a measure of stress resulting from interpersonal income comparisons.

This paper focuses on relationships between costs of monetary integration expressed in aggregate relative deprivation terms and macroeconomic imbalances observed by 12 European countries that adopted the euro in 1999-2001. This paper has empirical character and does not seek to understand the channels through which aggregate relative deprivation $(A R D)$ might influence the evolution of macroeconomic imbalances in the euro area member states.

As it is likely that macroeconomic effects of individual feelings of relative deprivation associated with increased scale of income comparisons cannot be observed in the short term, this paper analyzes cumulative changes in the price level, real effective exchange rate and unemployment rate, as well as sums of budgetary deficits/surpluses and current account deficits/surpluses calculated since the adoption of the euro.

On the basis of Eurostat (2016) data it is demonstrated empirically that in euro area greater cumulative costs of monetary integration expressed in $A R D$ terms (" $A R D$ losses") are positively correlated with greater cumulative increase in the general price level, greater cumulative increase in the unemployment rate and greater sums of budgetary deficits. However, no statistically significant relationship was found 
for cumulative appreciation of the real effective exchange rate, nor sums of current account deficits.

The paper is organized as follows. Subsequent sections explain how to measure costs of monetary integration expressed in $A R D$ terms, and present data and methodology. Then, the impact of "ARD losses" on selected variables depicting macroeconomic imbalances is estimated. Final section concludes.

\section{Measuring the costs and benefits of European monetary integra- tion in ARD terms}

Considerations conducted in this paper are based on Stark \& Wlodarczyk (2015). Accordingly, aggregate relative deprivation $(A R D)$ is calculated as the sum of the levels of stress resulting from income-based comparisons experienced by all the individuals in a particular euro area member country or in the euro area as a composite entity, following the equation:

$$
A R D=\sum_{i=1}^{n-1} R D\left(x_{i}\right)=\sum_{i=1}^{n-1}\left[1-F\left(x_{i}\right)\right] \cdot E\left(x-x_{i} \mid x>x_{i}\right)
$$

where $R D\left(x_{i}\right)$ is the relative deprivation experienced by individual $i, F\left(x_{i}\right)$ is the fraction of those in a population of $n$ members whose incomes are smaller than or equal to $x_{i}$, and $E\left(x-x_{i} \mid x>x_{i}\right)$ is the mean excess income.

This paper refers to an ideal situation of perfect wage transparency in which every individual used to conduct within-country income comparisons until the day of adoption of the euro and then started to compare himself with all the other individuals from the euro area. In reality, values of aggregate relative deprivation should be lower than obtained results and depend on individual perceptions of reference groups.

Stark \& Wlodarczyk (2015) assumed that " $A R D$ gains (losses)" occur when the values of $A R D$ calculated for a given country as a member of the euro area (including within-area comparisons) are lower (greater) than hypothetical values of $A R D$ calculated for each country separately (allowing for within-country comparisons only). They demonstrate that the distribution of the costs and benefits from monetary integration (evaluated in terms of $A R D$ ) is uneven and that the sum of " $A R D$ losses" is greater than the sum of "ARD gains". In general, monetary integration is 
$A R D$-detrimental for individuals from low-income countries who start to observe more individuals with higher incomes from other countries.

This paper is based on the assumption that "ARD gains" and " $A R D$ losses" can be summed up exactly in the same way as budget surpluses and deficits accumulate over time. Thus cumulative costs and benefits of joining the euro area in terms of $A R D$ are understood as the sum of differences between hypothetical value of $A R D$ without adopting the euro and $A R D$ in the monetary union. Therefore, cumulative "ARD gains" (hereafter $C A R D G$ ) for country $j$ are calculated as:

$$
C A R D G^{j}=\sum_{t=0}^{t=n}\left(A R D^{j}{ }_{\text {within-county }}-A R D^{j}{ }_{\text {within-EMU }}\right)
$$

If $C A R D G>0$, a country experiences net gains from monetary integration in terms of $A R D$, but if $C A R D G<0$, a country incurs a net loss during the period of analysis.

\section{Data and methodology}

From a macroeconomic perspective, aggregate relative deprivation can be calculated as:

$$
A R D=G \cdot n \cdot \bar{x}
$$

where $G$ stands for the Gini coefficient, $n$ is the population size, and $\bar{x}$ represents a measure of mean income. Therefore, data on the Gini coefficient of equivalized disposable income, on population size as of January 1 of each analyzed year, and on two measures of mean income: nominal GDP per capita (hereafter GDPPC) and GDP per capita in Purchasing Power Standards (hereafter GDPPPS) for 12 European countries that adopted the euro in 1999-2001 were extracted from the Eurostat Statistics Database $(2016)^{2}$. Consequently, two alternative variables measuring cumulative

2 In fact, Eurostat does not provide data on the Gini coefficient for the euro area as a composite entity on account of its changing composition. Therefore, extracted data were used to reconstruct income vectors of each member country and the euro area as a whole (to obtain comparable results) on the basis of equation (1). For details and assumptions underlying this procedure see Stark \& Wlodarczyk (2015). 
costs and benefits of joining the euro area in terms of $A R D$ are obtained (CARDG_GDPPC and CARDG_GDPPPS, respectively).

Other variables used in regressions (either as measures of macroeconomic imbalances or control variables) are also obtained on the basis of data extracted from the Eurostat Statistics Database (2016) and include:

a) HICP - an index of cumulative increase in the general price level calculated on the basis of annual average of all-items HICP (the year of euro adoption $=100$ );

b) REER - an index of cumulative increase in the real effective exchange rate deflated by unit labour costs in the total economy calculated for 37 trading partners (the year of euro adoption $=100$ );

c) $\mathrm{CA}$ - a sum of current account deficits/surpluses since the euro adoption calculated for unadjusted data covering all countries of the world (in billions of euro);

d) UNEMP - an increase in the unemployment rate between the year of euro adoption and 2014 (in percentage points);

e) BUDG - a sum of general government budget deficits/surpluses since the euro adoption (in billions of euro);

f) PAST_INFL - an average of all-items HICP during a three-year period preceding euro adoption (as percentage);

g) PAST_GOV_BOND - an average of long-term government bond yields during a three-year period preceding euro adoption (as percentage),

h) GDPPC_0 - gross domestic product per capita at market prices during the year of euro adoption (in thousands of euro);

i) GDP - an index of cumulative increase in the gross domestic product at market prices (the year of euro adoption $=100$ );

j) REAL_PROD - an index of cumulative increase in the real labour productivity per hour worked (the year of euro adoption $=100$ );

k) LAB_COSTS - an absolute increase in the total labour costs between the year 2000 and 2014 (in euro);

1) LAB_COSTS_REL - a relative increase in the total labour costs between the year 2000 and 2014.

Availability of data restricts time period of analysis to 1999-2014 (only variable CA is based on the period 1999-2013). In case of Greece which adopted the euro 
in 2001, variables are provided for the period 2001-2014. In case of Luxembourg some missing data are extrapolated. Summary statistics of variables discussed above are reported in table 1.

Table 1 . Summary statistics of analyzed data

\begin{tabular}{|c|r|r|r|r|c|}
\hline Variable & Mean & Median & Minimum & Maximum & $\begin{array}{c}\text { Standard de- } \\
\text { viation }\end{array}$ \\
\hline CARDG_GDPPC & $-1,596$ & 2,401 & $-27,140$ & 15,047 & 11,830 \\
\hline CARDG_GDPPPS & $-0,624$ & 0,574 & $-10,278$ & 11,097 & 6,085 \\
\hline HICP & 137,098 & 136,740 & 127,586 & 147,252 & 5,638 \\
\hline REER & 108,356 & 108,982 & 93,493 & 128,602 & 9,229 \\
\hline CA & 76,563 & 11,664 & $-670,189$ & 1599,130 & 554,028 \\
\hline UNEMP & 3,842 & 2,500 & $-3,600$ & 15,800 & 5,563 \\
\hline BUDG & $-331,790$ & $-158,636$ & $-1098,930$ & 32,900 & 359,084 \\
\hline PAST_INFL & 1,819 & 1,633 & 1,100 & 3,167 & 0,677 \\
\hline PAST_GOV_BOND & 5,775 & 5,670 & 4,793 & 7,050 & 0,676 \\
\hline GDPPC_0 & 23,967 & 24,250 & 11,700 & 53,000 & 10,448 \\
\hline GDP & 122,807 & 122,733 & 93,728 & 162,393 & 18,734 \\
\hline REAL_PROD & 116,475 & 116,364 & 103,163 & 146,832 & 11,405 \\
\hline LAB_COSTS & 8,692 & 9,500 & 2,700 & 14,600 & 3,494 \\
\hline LAB_COSTS_REL & 0,437 & 0,456 & 0,186 & 0,651 & 0,132 \\
\hline
\end{tabular}

Source: Author's elaboration based on Eurostat (2016).

To identify the effects of cumulative costs and benefits of joining the euro area in terms of $A R D$ as well as other variables on macroeconomic imbalances in a longer perspective, afollowing set of cross-sectional regressions is estimated

$$
Y=f\left(\mathrm{CARDG}, X_{l}, \ldots, X_{n}\right)
$$

where $Y$, the dependent variable, denotes selected variables depicting macroeconomic imbalances (HICP, REER, CA, UNEMP and BUDG), CARDG stands for cumulative gains and losses of joining the euro area in terms of $A R D$ (following equation (2)) for two measures of mean income (CARDG_GDPPC and CARDG_GDPPPS), while $X_{i}$ represent control variables. To estimate the model OLS regressions are used. 


\section{Results}

Main estimation results are reported in table 2. The estimated coefficients of cumulative gains of joining the euro area in terms of ARD calculated for two measures of mean income are negative and statistically significant in models 1-3 where the dependent variable is the index of cumulative increase in the general price level. Negative sign means that greater gains (in terms of $A R D$ ) are associated with smaller increase in the general price level and conversely, countries experiencing social costs of monetary integration are also expected to observe greater increases in the general price level (higher inflation).

This result is in accordance with economic literature and simple intuition. As signaled earlier, already before its introduction the euro was expected to increase wage pressures, especially in euro area countries with relatively low levels of income per capita, because workers and trade unions were likely to translate the wage transparency achieved within the monetary union into higher wage demands. This in turn could mean higher unemployment rate in these countries and higher demand for expenditures from the European Union budget (e.g. Welfens, 1998). Simultaneously, companies from these countries could observe reduced margins (resulting from higher labor costs and lower prices associated with both wage and price transparency) which could have a detrimental impact on their competitiveness and might lead to appreciation of the real effective exchange rate. In fact, even if the higher wage demand was not satisfied it could be associated with country's decreasing competitiveness, because of lower effort exerted by individuals with lower income, their lower productivity, higher unemployment rate and higher values of Gini coefficient (cf. Akerlof, Yellen, 1990).

Other estimation results confirm at least some of these predictions. Negative and statistically significant coefficient of CARDG_GDPPC in model 6 means that greater gains (in terms of $A R D$ ) are associated with smaller increases in the unemployment rate. On the other hand, countries experiencing social costs of monetary integration are also expected to observe greater increases in the unemployment rate. Positive and statistically significant coefficient of CARDG_GDPPPS in model 8 means that greater gains (in terms of $A R D$ ) are associated with a better fiscal situation, while countries characterized by high costs of monetary integration are much 
more likely to experience significant budget deficits. Nevertheless, one has to notice low value of $\mathrm{R}^{2}$ in model 8 .

Table 2. Estimation results of OLS regressions

$[*, * *, * * *$ represent respectively the level of significance of $1 \%, 5 \%$ and $10 \%]$

\begin{tabular}{|c|c|c|c|c|c|c|c|c|}
\hline $\begin{array}{l}\text { Dependent } \\
\text { variable }\end{array}$ & HICP & HICP & HICP & REER & $\mathrm{CA}$ & UNEMP & UNEMP & BUDG \\
\hline $\begin{array}{c}\text { Independent } \\
\text { variables }\end{array}$ & Model 1 & Model 2 & Model 3 & Model 4 & Model 5 & Model 6 & Model 7 & Model 8 \\
\hline 1 & 2 & 3 & 4 & 5 & 6 & 7 & 8 & 9 \\
\hline $\begin{array}{c}\text { CARDG_- }_{\text {GDPPC }} \\
\text { GDP }\end{array}$ & $\begin{array}{c}-0.418 \\
(0.043) \\
* * *\end{array}$ & $\begin{array}{c}-0.422 \\
(0.053) \\
* * *\end{array}$ & & $\begin{array}{c}0.183 \\
(0.118)\end{array}$ & $\begin{array}{c}26.446 \\
(14.972)\end{array}$ & $\begin{array}{c}-0.482 \\
(0.155) \\
* *\end{array}$ & & \\
\hline $\begin{array}{l}\text { CARDG }_{\text {GDPPPS }}\end{array}$ & & & $\begin{array}{c}-0.599 \\
(0.290) \\
*\end{array}$ & & & & $\begin{array}{l}-0.220 \\
(0.226)\end{array}$ & $\begin{array}{c}44.261 \\
(22.117) \\
*\end{array}$ \\
\hline HICP & & & & & & & $\begin{array}{c}0.961 \\
(0.293) \\
* *\end{array}$ & $\begin{array}{c}25.070 \\
(20.402)\end{array}$ \\
\hline REER & & & & & $\begin{array}{c}-50.779 \\
(23.238) \\
*\end{array}$ & & & \\
\hline $\mathrm{CA}$ & & & & $\begin{array}{c}-0.011 \\
(0.002) \\
* * *\end{array}$ & & & & \\
\hline UNEMP & & & & & & & & $\begin{array}{c}27.762 \\
(24.040)\end{array}$ \\
\hline BUDG & & $\begin{array}{c}0.001 \\
(0.001)\end{array}$ & & & & & & \\
\hline PAST_INFL & $\begin{array}{c}3.909 \\
(0.973) \\
* * *\end{array}$ & $\begin{array}{c}3.740 \\
(1.153) \\
* *\end{array}$ & $\begin{array}{c}3.773 \\
(2.939)\end{array}$ & & & & & \\
\hline $\begin{array}{c}\text { PAST_GOV_- } \\
\text { BOND }\end{array}$ & $\begin{array}{c}-2.620 \\
(0.733) \\
* *\end{array}$ & $\begin{array}{c}-2.407 \\
(0.833) \\
* *\end{array}$ & & & & & & \\
\hline GDPPC_0 & $\begin{array}{c}0.430 \\
(0.025) \\
* * *\end{array}$ & $\begin{array}{c}0.400 \\
(0.031) \\
* * *\end{array}$ & $\begin{array}{c}0.427 \\
(0.075) \\
* * *\end{array}$ & $\begin{array}{c}0.513 \\
(0.064) \\
* * *\end{array}$ & $\begin{array}{c}27.023 \\
(34.701)\end{array}$ & $\begin{array}{c}0.302 \\
(0.282)\end{array}$ & & \\
\hline GDP & & $\begin{array}{c}0.022 \\
(0.026)\end{array}$ & & & $\begin{array}{l}-3.609 \\
(17.051)\end{array}$ & $\begin{array}{l}-0.171 \\
(0.194)\end{array}$ & $\begin{array}{c}-0.175 \\
(0.077) \\
*\end{array}$ & \\
\hline $\begin{array}{l}\text { REAL }_{-} \\
\text {PROD }\end{array}$ & & & & $\begin{array}{c}-0.408 \\
(0.092) \\
* * *\end{array}$ & $\begin{array}{l}-19.687 \\
(25.114)\end{array}$ & $\begin{array}{c}0.340 \\
(0.242)\end{array}$ & $\begin{array}{c}0.414 \\
(0.143) \\
* *\end{array}$ & \\
\hline LAB_COSTS & & & $\begin{array}{c}0.121 \\
(0.217)\end{array}$ & & & & & \\
\hline
\end{tabular}




\begin{tabular}{|c|c|c|c|c|c|c|c|c|}
\hline 1 & 2 & 3 & 4 & 5 & 6 & 7 & 8 & 9 \\
\hline LAB_ & $\begin{array}{c}10.753 \\
(1.871) \\
* * *\end{array}$ & $\begin{array}{c}7.845 \\
(3.678) \\
*\end{array}$ & & & & -7.837 & -19.633 & 1105.390 \\
$(611.225)$ & $(14.583)$ & $(14.088)$ & \\
\hline $\mathrm{R}^{2}$ & 0.98 & 0.99 & 0.71 & 0.87 & 0.83 & 0.60 & 0.78 & 0.47 \\
\hline
\end{tabular}

Note: In parentheses White's heteroskedasticity-consistent standard errors (variant HC1) are reported.

Source: Author's calculations based on Eurostat (2016).

Coefficients of CARDG_GDPPC obtained in model 4 and 5 are not statistically significant, but their values do not contradict the character of expected relationships. One may expect greater gains of joining the euro area in terms of $A R D$ to be associated with a depreciation of the real effective exchange rate or an appreciation that is much weaker than in countries experiencing "ARD losses". This explains a close to zero, but positive value of coefficient in model 4. Similarly, one may expect a positive relationship between "ARD gains (losses)" and current account surpluses (deficits) as predicted by model 5 .

\section{Concluding remarks}

According to the Committee on the Study of Economic and Monetary Union (1989), the euro area was expected to bring about a significant increase in economic welfare. However, adequate structural adjustments (as well as highly compatible economic policies, in particular in the fiscal domain) were seen necessary to spread these welfare gains among constituent countries and to avoid persistent macroeconomic imbalances. Otherwise, the overall impact on peripheral regions was expected to be negative. Recent developments in the euro area confirm that these concerns were justified.

This paper puts the problem of macroeconomic imbalances in the euro area in an unconventional perspective, emphasizing the social aspects of circulation of a single currency, including the increase of aggregate relative deprivation as a consequence of more intense income comparisons between individuals from different euro area countries.

This paper demonstrated that the impact of cumulative costs and benefits of adopting the euro in terms of $A R D$ on cumulative increase in the general price level 
is strong. There are also relatively weak (but statistically significant) relationships between these costs and cumulative increase in the unemployment rate or the sum of general government budget deficits/surpluses since the euro adoption. Nevertheless, there seem to be no statistically significant relationship between cumulative costs and benefits of adopting the euro in terms of $A R D$ and cumulative appreciation of the real effective exchange rate, nor the sums of current account deficits/surpluses.

Naturally, these conclusions have a preliminary character and one should take into account significant limitations of the methodology proposed in this paper. Further research could focus on building more comprehensive models, including e.g. more in-depth analyses of country specific patterns and experience of later entrants or on investigating possible channels through which aggregate relative deprivation might influence the evolution of macroeconomic imbalances in the euro area.

\section{References}

Akerlof, G.A., Yellen, J.L. (1990). The Fair-Wage Hypothesis and Unemployment. Quarterly Journal of Economics, 105 (2), 255-283.

Clark, A.E., Senik, C. (2010). Who Compares to Whom? The Anatomy of Income Comparisons in Europe. The Economic Journal, 120, 573-594. DOI: 10.1111/J.14680297.2010.02359.X.

Committee on the Study of Economic and Monetary Union (the Delors Committee) (1989). Report on Economic and Monetary Union in the European Community.

Eurostat (2016). Retrieved from: http://epp.eurostat.ec.europa.eu (30.04.2015).

Holinski, N., Kool, C., Muysken, J. (2010). Origins of Persistent Macroeconomic Imbalances in the Euro Area. Tjalling C. Koopmans Research Institute, Discussion Paper Series no. 10-12. Utrecht School of Economics, Utrecht University.

Stark, O., Wlodarczyk, J. (2015). European Monetary Integration and Aggregate Relative Deprivation: The Dull Side of the Shiny Euro. Economics and Politics, 27 (2), 185203. DOI: 10.1111/ecpo.12059.

Welfens, P.J.J. (1998). Facing the Euro: Prospects for Growth or Stagnation? Intereconomics. Review of European Economic Policy, 33 (3), 112-117. 


\section{ZAGREGOWANA RELATYWNA DEPRYWACJA A NIERÓWNOWAGI MAKROEKONOMICZNE W STREFIE EURO - PIERWSZE SPOJRZENIE}

\section{Streszczenie}

Niniejszy artykuł przedstawia kwestię nierównowag makroekonomicznych w strefie euro w niekonwencjonalnej perspektywie, koncentrując się na zwiększonej intensywności interpersonalnych porównań dochodów między jednostkami z różnych krajów strefy euro po wprowadzeniu wspólnej waluty. Koszty i korzyści z integracji, związane z bardziej intensywnymi porównaniami dochodów, wyrażone są w kategoriach zagregowanej relatywnej deprywacji $(A R D)$. Zademonstrowano empirycznie, iż większe koszty integracji monetarnej wyrażone w kategoriach zagregowanej relatywnej deprywacji są pozytywnie skorelowane z przyśpieszonym wzrostem ogólnego poziomu cen, stopy bezrobocia oraz z większymi deficytami budżetowymi. Nie wykazano istotnej statystycznie zależności z aprecjacją realnego efektywnego kursu walutowego ani deficytami w rachunku obrotów bieżących.

Słowa kluczowe: zagregowana relatywna deprywacja, porównania dochodów, nierównowagi makroekonomiczne, inflacja, bezrobocie

JEL codes: F45, D63 
